\title{
PENINGKATAN KEMAMPUAN PEMECAHAN MASALAH MAHASISWA DIII TEKNIK MESIN DENGAN SOFTWARE WOLFRAM MATHEMATICA
}

\author{
M. Taufik Qurohman ${ }^{1}$, Syaefani Arif Romadhon ${ }^{2}$, Muchamad Sobri Sungkar ${ }^{3}$ \\ 1, 2, 3 Politeknik Harapan Bersama, J1. Mataram No.9 Pesurungan, Kota Tegal, Indonesia. \\ taufikqurohman87@gmail.com
}

\begin{abstract}
This research aims to improve problem solving skills by integrating computing technology using Wolfram Mathematica software. The researh is a CAR with Four stages namely planing, acting, observing, reflecting. Result carried out with the application of Wolfram Mathematica computational learning innovation are as follows: (1) The results of the questionnaire recap which have been distributed and filled in directly by students have a $24 \%$ percentage increase to $88 \%$ in the cycle to, (2) There is an increase in activity student learning with a description in cycle 1 has a percentage of $63 \%$ who have a level of activity at the level of moderately active, and in cycle II of $75 \%$ who have a level of activity at an active level, (3) There are also inccrease the ability to solve students, the level of activity, and interest in learning for students is seen by the indicator of the average value in cycle 1 is 65 and the level of student learning completeness with 55\% achievement. Then the average value of students in cycle 2 is obtained with a level 77 and the completeness learning process reaches $98 \%$, be concluded that the increase from every cycle is very significant and effective.
\end{abstract}

Keywords: Problem Solving Ability, Wolfram Mathematica, Engineering Mathematics 2

\begin{abstract}
Abstrak
Dalam penelitian ini populasi adalah Mahasiswa Prodi DIII Teknik Mesin, kemudian untuk sampel yang digunakan adalah kelas 2B yang merupakan mahasiswa semester 2 Tahun Akademik 2019/2020. Penelitian ini memiliki tujuan meningkatkan kemampuan pemecahan masalah yang dengan memadukan teknologi komputasi mengunakan software Wolfram Mathematica. Penelitian merupakan Penelitian Tindakan Kelas dengan 4 tahap yaitu Planning, Acting, Observing, Reflecting. Hasil riset yang telah dilaksanakan dengan aplikasi inovasi pembelajaran komputasi Wolfram Mathematica adalah sebagai berikut : (1) Hasil Rekap kuisioner yang telah dibagikan dan dan di isi langsung oleh mahasiswa memiliki prosentase $24 \%$ meningkat menjadi $88 \%$ pada siklus ke, (2) Terdapat peningkatan aktifitas belajar mahasiswa dengan diskripsi pada siklus 1 memiliki Prosentase $63 \%$ yang memiliki tingkat keaktifan pada tingkat cukup aktif, dan pada siklus II sebesar $75 \%$ yang memiliki tingkat keaktifan pada tingkat aktif, (3) Terdapat pula pengingkatan pada kemampuan pemecahan mahasiswa, tingkat keaktifan, dan minat belajar pada mahasiswa yang terlihat dengan indikator perolehan nilai rerata mahasiswa pada siklus 1 sebesar 65 serta tingkat ketuntasan belajar mahasiswa dengan capaian $55 \%$. Kemudian nilai rerata mahasiswa di siklus 2 di peroleh dengan tingkat 77 serta tingkat ketuntasan mahasiswa dalam proses pembelajaran mencapai $98 \%$, sehingga dapat di simpulkan terdapat perubahan positif yang sangat siginifikan dan efektif.
\end{abstract}

Kata kunci: Kemampuan Pemecahan Masalah, Wolfram Mathematica, Matematika Teknik 2

\section{PENDAHULUAN}

Kita ketahui bersama bahwa saat ini terjadi pandemi pada tahun 2020 dimana perkuliahan semester genap tahun akademik 2019/2020 yang pada akhirnya membuat pembelajaran menjadi serba online dimana semua pembelajaran yang tadinya dilakukan secara tatap muka, hal ini tentu saja menjadikan proses pembelajaran menjadi terasa berbeda. Karena kondisi seperti tidak pernah di prediksi sebelumnya namun hal ini tidak mengurangi semangat mahasiswa maupun dosen yang melaksanakan perkuliahan khusus di Politeknik Harapan Bersama. Pada penelitian ini ketika awal konsep akan menggunakan pembelajaran dengan tatap muka, namun dalam perjalannya akhirnya menggunakan pembelajaran multimedia berbasis internet. Namun pada komputasi software Wolfram 
Matematika yang di gunakan sebagai alat bantu untuk meningkatkan prestasi pembelajaran pada matakuliah matematika teknik 2 masih di rasa sangat efektif. Dan dasar penggunaan Komputasi Wolfram Mathematica ini, karena pada penelitian sebelumnya terbukti dapat meningkatkan minat, berpikir kritis, dan dan meningkatkan kemampuan pemecahan masalah (Sunaryo, 2020). Terkait kemampuan pemecahan masalah pada penelitian ini, pada prosesnya dilakukan pembelajaran yang unik karena mahasiswa diminta untuk memadukan pemahaman awal mereka kemudian meningkatkan kemampuan dalam menentukan solusi yang efektif (Romadhon \& Qurohman, 2017).

Kebaharuan dalam penelitian ini adalah bagaimana kemudian memadukan pembelajaran yang awalnya tidak menggunakan alat bantu untuk menyelesaikan permasalahan khusunya dalam matakuliah matematika teknik 2 dimana memadukan komputasi Wolfram Mathematica ini cukup efektif karena di dalam dalam menyelesaikan soal2 dan kemudian memadukan dengan Teknologi berbasis komputer, yang dimana perintah yang dimasukan juga bersifat prosedur yang urut, sehingga menjadikan mahasiswa dapat meningkatkan kemandirian, berpikir kreatif, dan meningkatkan prestasi (Muhtarom et al., 2015; R \& Qurohman, 2018; Shodiqin \& Belakang, 1995).

Wolfram Mathematica sendiri merupakan program komputasi ini didirikan oleh Stephen Wolfram pada tahun 1987, dimana software ini menyelesaikan berbagai persoalan matematika seperti aljabar, integral, matrik dan grafik (Haswati, D., \& Nopitasari, D., 2019). Penyelesaikan dengan software ini dirasa efektif karena menggunakan penyelasaian secara fungsional bukan toolbox, serta software ini memiliki kelebihan yaitu memiliki kecepatan seamless connctivity, seamless deployment dan integrated platform (Sunaryo, 2020). Sehingga dengan banyak kelebihan software ini diharapkan dapat menjadi salah satu produk yang dapat di padukan dalam proses pembelajaran saat ini. Dan penggunakan teknologi komputasi memang sangat selaras dengan era revolusi indrustri 4.0.

\section{METODE}

Pada penelitian yang dilakukan karena jenis Classroom Action Research sehingga terdapat beberapa tahapan yang digunakan, hal ini dapat dilihat pada Gambar 1: Tahap siklus yang digunakan adalah 2 siklus dan apabila di perlukan siklus dapat di tambah, ketika tidak ada perubahan signifikan antara siklus 1 dan siklus 2 .

Langkah penelitian dilakukan dengan langkah - langkah berikut :

Data Penelitian/Riset, Dengan teknik pengumpulan data khusus dan data tambahan.

Pengolahan Data, Pengolahan data dilakukan untuk mengetahui kemampuan pemecahan masalah dan kemampuan awal mahasiswa.

Kegiatan Silkus I, Kegiatan dengan menggunakan Metode Pembelajaran ceramah biasa dengan proses Planning, Acting, Observing, Reflecting.

Inovasi Pembelajaran, Dengan mengunakan tambahan software komputasi dalam proses pembelajaran. 


\section{Siklus II}

Dengan memadukan proses pembelajaran pada komputasi matematika menggunakan wolfram mathematica dengan proses : Planning, Acting, Observing, Reflecting.

\section{Proses Evaluasi}

Dengan mengolah hasil hasil evaluasi dari setiap siklus.

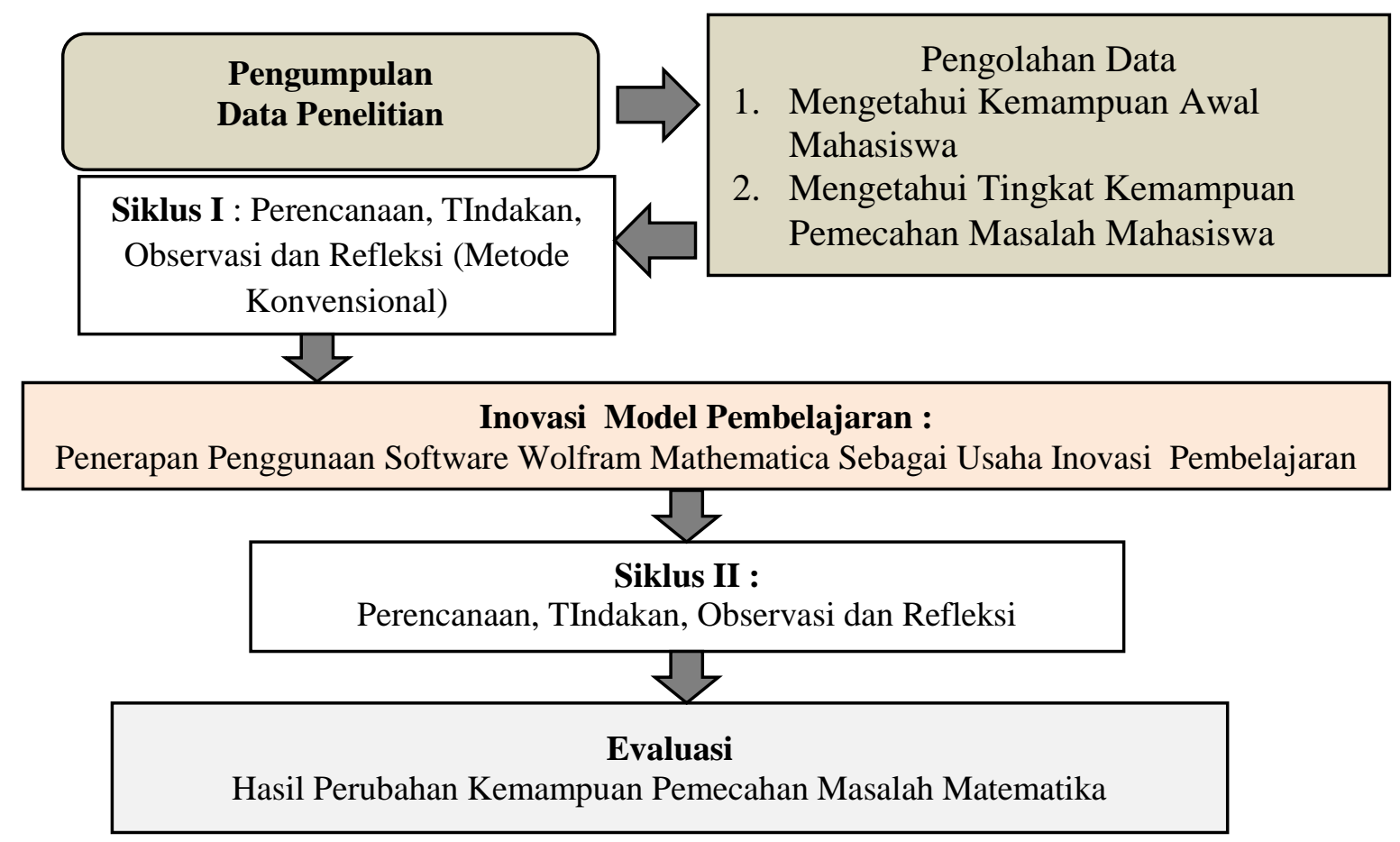

Gambar 1. Tahapan Pelaksanaan Riset

Riset ini memakai metode Classroom Action Research, dimana penelitian ini menggunakan metode pembelajaran dengan bantuan sofware komputasi wolfram mathematica untuk memperoleh hasil perubahan prestasi belajar dengan inovasi pembelajaran. Dengan tujuan untuk memperoleh model pembelajaran dengan hasil terbaik. Rancangan desain riset secara prosedur terlihat pada Gambar 2.

Siklus I:

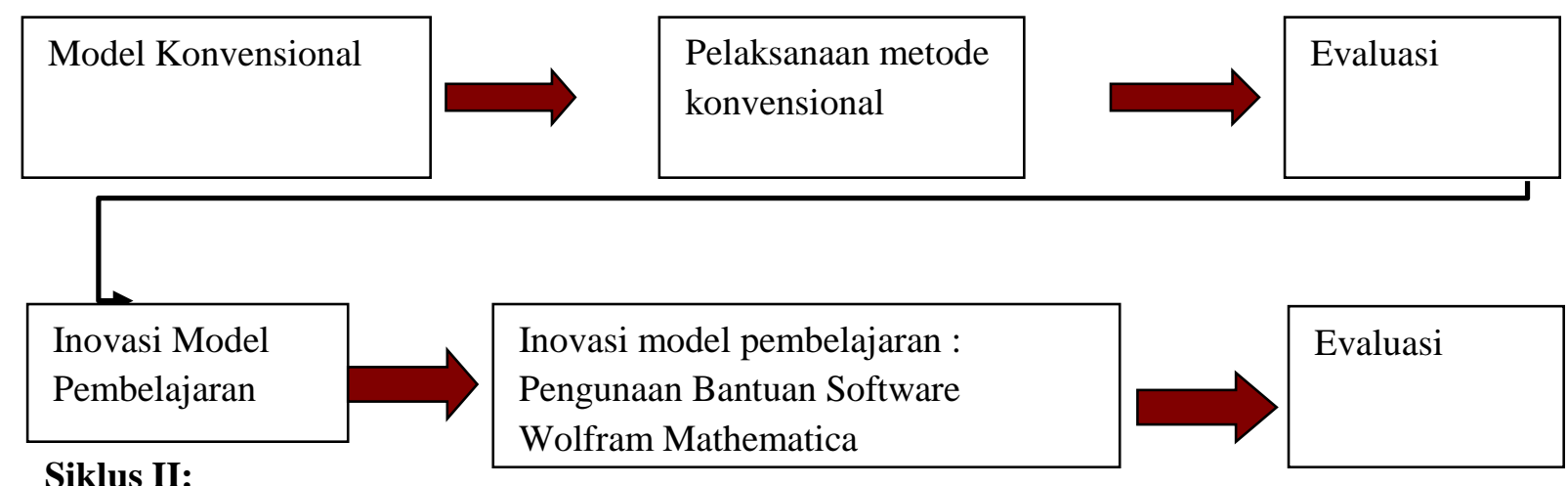

Gambar 2. Prosedur Desain Riset 
Terlihat pada prosedur desain riset menggambarkan bahwa mengolah perubahan hasil prestasi dari 2 siklus yang dilaksanakan kemudian mengambil kesimpulan dengan menggunakan parameter yang lebih tinggi nilai prestasi dengan menggunkan inovasi dan tanpa inovasi pembelajaran.

Proses riset ini yaitu melalui tahapan dengan langkah pertama kali adalah pembuatan tabel kemudian langkah selanjutnya dilakukan analisa data. Proses analisa yang dilakukan adalah kualitatif, dengan melihat rerata nilai Kemampuan Pemecahan Masalah Mahasiswa. Kemudian langkah selanjutnya adalah dengan membandingkan nilai ketutasan dengan tingkat prosesntase. Nilai awal di peroleh dari data nilai mahasiswa pada semester sebelumnya. Dan nilai observasi kemampuan pemecahan masalah mahasiswa dibuat tabulasi kemudian di hitung prosentasenya. Dengan metode kualitatif diperoleh hasil akhir penelitian dengan deskripsi hasil pembelajaran secara rinci dan jelas.

\section{HASIL}

Riset pada kesempatan kali ini berpusat menggunakan bantuan komputasi dimana komputasi yang digunakan adalah suatu software Wolfram Mathematica dan penelitian ini merupakan eksperimen dengan mengamati proses pada kelas yang dijadikan sampel. Dan diperoleh data berikut :

\section{Siklus I}

Kegiatan siklus I berorientasi pada pegukuran kemampuan proses pembelajaran yang melihat Kemampuan Pemecahan Masalah Mahasiswa dengan menggunakan proses sebagai berikut :

\section{Rencana Tindakan}

Kegiatan ini meliputi :

a. Pengadaan Lengkap perangkat pembelajaran secara lengkap yang terdiri dari RPP, RPS, dan Evaluasi untuk mengukur kemampuan mahasiswa terkait dengan peningkatan Kemampuan Pemecahan Masalah Mahasiswa.

b. Melakukan koordinasi dengan Teman sejawat, dalam hal ini rekan sejawat yang dimaksud adalah dosen yang melakukan observer (pengamatan) dalam proses pembelajaran.

c. Melaksanakan kegiatan penilaian berupa evaluasi untuk mengetahui kemampuan awal mahasiswa dengan menggunakan nilai sebelumnya yang berkaitan dengan matakuliah terkait.

\section{Pelaksanaan Kegiatan}

Kegiatan yang dilaksanakan pada siklus I memiliki rencana pertemuan sebanyak 7 kali pertemuan dimana dalam pelaksanaan pemebelajarannya menggunakan waktu 2 x50 menit dimana kegiatan dilanjutkan dengan kegiatan pengambilan nilai kemapuan awal selama 1 Jam. Langkah sebagai berikut :

a. Pendidik/Dosen melaksanakan kegiatan pembukaan kegiatan belajar dengan memberikan motivasi dan apersepsi terkait dengan matakuliah yang akan diajarkan. 
b. Pendidik/Dosen melakukan kegiatan pemberian beberapa pertanyaan ke mahasiswa sebagai bentuk peninjuan kemampuan awal khusus matakuliah Matematika Teknik 2. Kemudian menghubungkan materi dengan kehidupan nyata (sehari - hari).

c. Mahasiswa melakukan kegiatan sharing terkait persoalan yang diberikan oleh Dosen, kemudian menjelaskan secara bergantian terkait alurnya. Kemudian Dosen membimbing untuk dapat menjabarkan kembali dengan rekontruksi yang jelas.

d. Memberikan mahasiswa lembar evaluasi berupa lembar kerja yang kemudian harus dikerjakan mandiri oleh mahasiswa. Dan Dosen mendampingi mahasiswa dalam mengerjakan lembar kerja tersebut, kemudian memberikan arahan dan bimbingan ketika mahasiswa mengalami kesulitan.

e. Langkah berikutnya Dosen memberikan arahan, agar mahasiswa dapat menyimpulkan materi yang telah diterima pada setiap akhir pertemuan.

f. Kemudian dengan menggunakan Komputasi Wolfram Mathematica mahasiswa di arahkan untuk menyelesaikan masalah terkait materi perkuliahan dengan penyelesaian yang cepat dan akurat, kemudian dengan kelompok yang sudah terbentuk membuat penyelesaian yang terpadu sehingga pada gilirannya mahasiswa dapat menyelesaian persoalan matematika dengan cepat dan tepat.

g. Di kegiatan penutup/Akhir pada siklus ini (Siklus 1), Dosen memberikan evaluasi terkait dengan matakuliah yang diberikan.

\section{Observasi dan Evaluasi}

Dengan pengolahan pada aspek keaktifan mahasiswa pada proses perkuliahan, tidak dapat dipungkiri masih terdapat banyak hal perlu untuk di tindaklanjuti, dan hal yang perlu untuk di observasi dan evaluasi adalah terkait motivasi pada matakuliah matematika teknik 2 dengan kehidupan nyata. Karena tidak dapat dipungkiri masih terdapat beberapa aspek yang terkait antara lain peningkatan motivasi dengan kamampuan pemecahan masalah. Dan dalam mengukur tingkat keaktifan mahasiswa yaitu dengan merekamnya dengan lembar observasi dan nantinya kan menjadi ringkasan analisis kemampuan mahasiswa yang terpadu. Hasil kesimpulan dari lembar observasi Aktifitas maupun kemampuan pemecahan masalah matematika (ketuntasan belajar), yang kemudian di analisis dengan aspek lainnya dalam proses menuju kesimpulan akhir.

\section{Refleksi}

Kegiatan refleksi mencakup bebebrapa aspek yang harus di persiapkan untuk memperoleh hasil evaluasi hasil akhir dengan memperhatikan tingkat ketuntasan belajar mahasiswa khususnya pada matakuliah matematika teknik 2, ketika hasil yang diharapkan pada siklus ini belum maksimal maka akan di adakan kegitan perbaikan. Kegiatan perbaikan tersebut meliputi : pada teknik pembelajaran yang perlu dilakukan inovasi yang berkekmbang baik ketika perangkat pembelajaran ketika proses pembelajaran maupun bentuk evaluasi yang di gunakan.

Dan kegiatan ini diperoleh data tingkat pemahaman dan beberapa temuan yang diantaranya adalah masih terdapat mahasiswa yang belum menguasai penggunaan teknologi komputer, hal ini terlihat ketika mahasiswa di pandu dalam menggunakan software komputasi matematika dalam hal ini adalah 
wolfram mathematica. Dan terkait prosedur penyelesaian pemecahan masalah mahasiswa ini, dan untuk keefektifan buku ajar juga masih dirasa kurang maksimal. Sehingga hasil akhir pada aspek refleksi ini melalui proses koordinasi antara observer dengan peneliti, dan diperoleh kesepakatan untuk menggunakan lebih banyak porsi media wolfram mathematica yang lebih dominan, dan penerapan belajar kelompok perlu di optimalkan lagi dengan memperketat kontrak perkulihan antara dosen dan mahasiswa.

\section{Siklus II}

Pada siklus II berorientasi pada penilaian akhir proses pembelajaran yang melihat Kemampuan Pemecahan Masalah Mahasiswa dengan menggunakan proses sebagai berikut :

\section{Rencana Tindakan}

Kegiatan ini meliputi :

a. Pengadaan Lengkap perangkat pembelajaran secara lengkap yang terdiri dari RPP, RPS, dan Evaluasi untuk mengukur kemampuan mahasiswa terkait dengan peningkatan Kemampuan Pemecahan Masalah Mahasiswa.

b. Melakukan koordinasi dengan Teman sejawat, dalam hal ini rekan sejawat yang dimaksud adalah dosen yang melakukan observer (pengamatan) dalam proses pembelajaran.

c. Melaksanakan kegiatan penilaian berupa evaluasi untuk mengetahui kemampuan awal mahasiswa dengan menggunakan nilai sebelumnya yang berkaitan dengan matakuliah terkait.

\section{Pelaksanaan Kegiatan}

Kegiatan yang dilaksanakan pada siklus I memiliki rencana pertemuan sebanyak 7 kali pertemuan dimana dalam pelaksanaan pemebelajarannya menggunakan waktu 2x50 menit dimana kegiatan dilanjutkan dengan kegiatan pengambilan nilai kemapuan awal selama 1 Jam. Dengan langkah berikut:

a. Pendidik/Dosen melaksanakan kegiatan pembukaan kegiatan belajar dengan memberikan motivasi dan apersepsi terkait dengan matakuliah yang akan diajarkan.

b. Pendidik/Dosen melakukan kegiatan pemberian beberapa pertanyaan ke mahasiswa sebagai bentuk peninjuan kemampuan awal khusus matakuliah Matematika Teknik 2. Kemudian menghubungkan materi dengan kehidupan nyata (sehari - hari).

c. Mahasiswa melakukan kegiatan sharing terkait persoalan yang diberikan oleh Dosen, kemudian menjelaskan secara bergantian terkait alurnya. Kemudian Dosen membimbing untuk dapat menjabarkan kembali dengan rekontruksi yang jelas.

d. Memberikan mahasiswa lembar evaluasi berupa lembar kerja yang kemudian harus dikerjakan mandiri oleh mahasiswa. Dan Dosen mendampingi mahasiswa dalam mengerjakan lembar kerja tersebut.

e. Langkah berikutnya Dosen memberikan arahan, agar mahasiswa dapat menyimpulkan materi yang telah diterima pada setiap akhir pertemuan. 
f. Kemudian dengan menggunakan Komputasi Wolfram Mathematica mahasiswa di arahkan untuk menyelesaikan masalah terkait materi perkuliahan dengan penyelesaian yang cepat dan akurat, kemudian dengan kelompok yang sudah terbentuk membuat penyelesaian yang terpadu sehingga pada gilirannya mahasiswa dapat menyelesaian persoalan matematika dengan cepat dan tepat.

g. Di kegiatan penutup/Akhir pada siklus ini (Siklus 1), Dosen memberikan evaluasi terkait dengan matakuliah yang diberikan.

\section{Observasi dan Evaluasi}

Dengan pengolahan pada aspek keaktifan mahasiswa pada proses perkuliahan, tidak dapat dipungkiri masih terdapat banyak hal perlu untuk di tindaklanjuti, dan hal yang perlu untuk di observasi dan evaluasi adalah terkait motivasi pada matakuliah matematika teknik 2 dengan kehidupan nyata. Karena tidak dapat dipungkiri masih terdapat beberapa aspek yang terkait antara lain peningkatan motivasi dengan kamampuan pemecahan masalah. Dan dalam mengukur tingkat keaktifan mahasiswa yaitu dengan merekamnya dengan lembar observasi dan nantinya kan menjadi ringkasan analisis kemampuan mahasiswa yang terpadu. Hasil kesimpulan dari lembar observasi Aktifitas maupun kemampuan pemecahan masalah matematika (ketuntasan belajar), yang kemudian di analisis dengan aspek lainnya dalam proses menuju kesimpulan akhir.

\section{Refleksi}

Kegiatan refleksi mencakup bebebrapa aspek yang harus di persiapkan untuk memperoleh hasil evaluasi hasil akhir dengan memperhatikan tingkat ketuntasan belajar mahasiswa khususnya pada matakuliah matematika teknik 2, ketika hasil yang diharapkan pada siklus ini belum maksimal maka akan di adakan kegitan perbaikan. Kegiatan perbaikan tersebut meliputi : pada teknik pembelajaran yang perlu dilakukan inovasi yang berkekmbang baik ketika perangkat pembelajaran ketika proses perkuliahan maupun bentuk evaluasi yang diberikan kepada mahasiswa. Pada siklus ini diperoleh hasil pemahaman dan beberapa temuan yang diantaranya adalah masih terdapat mahasiswa yang belum menguasai penggunaan teknologi komputer, hal ini terlihat ketika mahasiswa di pandu dalam menggunakan software komputasi matematika dalam hal ini adalah wolfram mathematica. Dan terkait prosedur penyelesaian pemecahan masalah mahasiswa ini, dan untuk keefektifan buku ajar juga masih dirasa kurang maksimal. Sehingga hasil akhir pada aspek refleksi ini melalui proses koordinasi antara observer dengan peneliti, dan diperoleh kesepakatan untuk menggunakan lebih banyak porsi media wolfram mathematica yang lebih dominan, dan penerapan belajar kelompok perlu di optimalkan lagi dengan memperketat kontrak perkulihan antara dosen dan mahasiswa.

\section{Analisa Data}

Hasil dari penelitian yang dilaksanakan terkait dengan Kemampuan Pemecahan Masalah Mahasiswa, aktifitas dan motivasi. Dimana untuk indikator soal evaluasi untuk mengukur Kemampuan Pemecahan Masalah Mahasiswa menggunakan tahap Pemecahan masalah : Memahami masalah, Merencanakan solusi, Melaksanakan solusi permasalahan, dan Mengevaluasi kembali. 
Peningkatan Kemampuan Pemecahan Masalah Mahasiswa DIII Teknik Mesin dengan Software Wolfram Mathematica, M. Taufik Qurohman, Syaefani Arif Romadhon, Muchamad Sobri Sungkar

\section{Kemampuan Pemecahan Masalah Mahasiswa}

Pemecahan masalah sebagai pendekatan dalam pembelajaran. Sedangkan menurut Polya terdapat dua masalah yaitu : 1. masalah untuk menemukan, dapat teoritis atau praktis, abstrak atau konkret, termasuk teka-teki. Bagian utama dari suatu masalah adalah sebagai berikut : a) Apa yang dicari?; b) Bagaimana data diketahui?; c) Bagaimana syaratnya?; Ketiga bagian utama tersebut merupakan landasan untuk dapat menyelesaikan masalah jenis ini; 2. Masalah untuk membuktikan adalah menunjukan bahwa suatu pertanyaan itu benar, salah atau kedua-duanya. Sehingga dapat disimpulkan ada 4 indikator Pemecahan Masalah sebagai berikut : Memahami masalah, Merencanakan solusi, Melaksanakan solusi permasalahan, dan Mengevaluasi kembali. (Evaluasi Akhir), di setiap siklus dapat terlihat secara rinci pada Tabel 1 .

Tabel 1. Analisa Kemampuan Pemecahan Masalah Mahasiswa

\begin{tabular}{lcc} 
Uraian & Siklus I & Siklus II \\
Nilai Teratas & 76 & 96 \\
Nilai Terbawah & 58 & 69 \\
Rerata & 65 & 77 \\
Total Mahasiswa & 25 & 25 \\
Total Mahasiswa Lulus & 14 & 24 \\
Total Mahasiswa Belum Lulus & 11 & 1 \\
Prosentase Mahasiswa Lulus & $55 \%$ & $98 \%$ \\
Prosentase Mahasiswa Belum Lulus & $45 \%$ & $2 \%$ \\
\hline
\end{tabular}

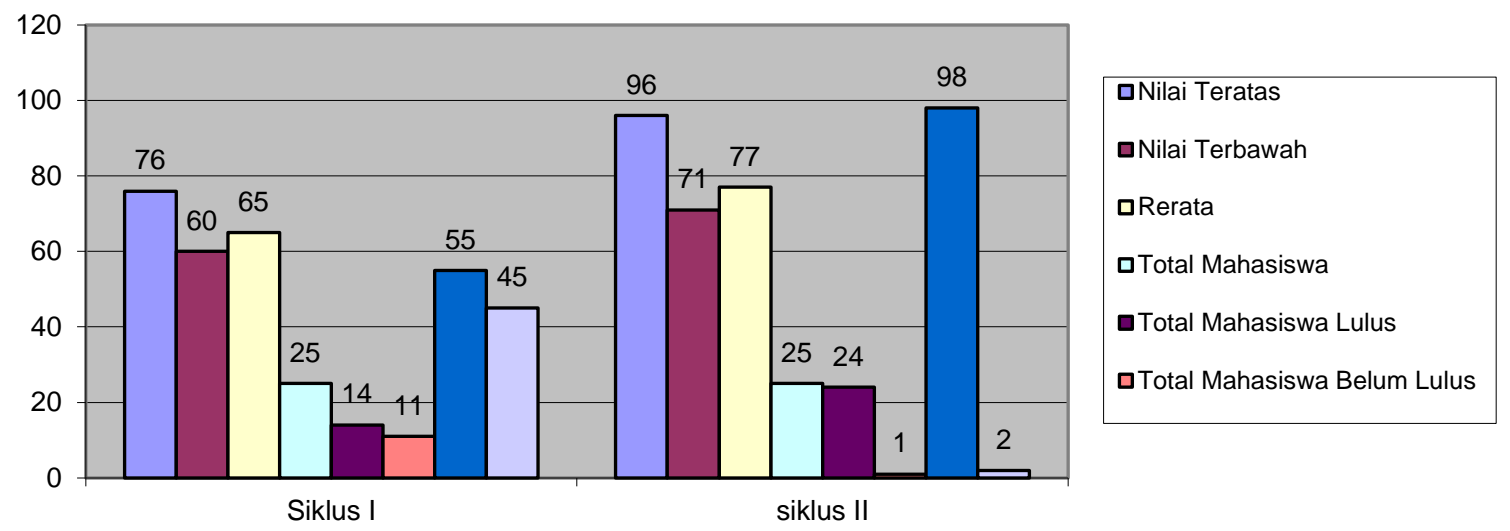

Gambar 1. Grafik Kemampuan Pemecahan Masalah Mahasiswa

\section{Aktifitas mahasiswa}

Dengan menggunakan data lembar observasi di setiap siklus, didapatkan data yang terangkum pada Tabel 2.

Tabel 2.

Rekapan Aktivitas Mahasiswa Siklus I dan II

\begin{tabular}{lcc}
\hline Uraian & Siklus I & Siklus II \\
Tidak Aktif & 9 & 6 \\
Cukup Aktif & 12 & 9 \\
Aktif & 4 & 10 \\
\hline
\end{tabular}




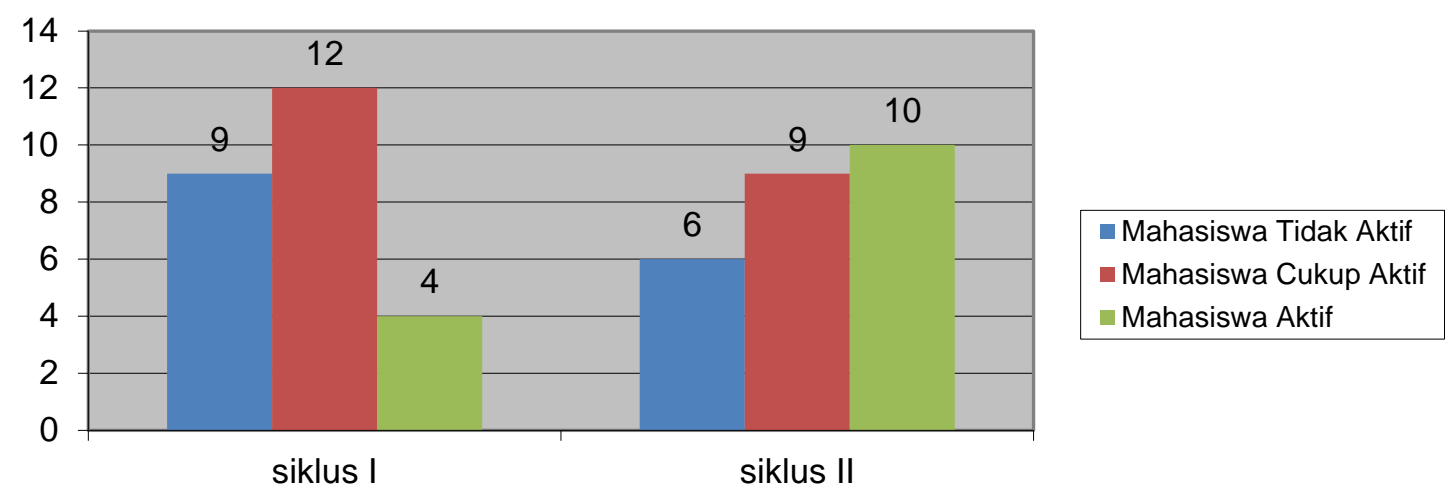

Gambar 2. Grafik Aktifitas Mahasiswa

\section{Motivasi}

Dengan melihat hasil angket yang telah di isi oleh mahasiswa, maka dapat disimpulkan dalam bentuk tabel 3.

\section{Tabel 3.}

Hasil Analisa Minat Mahasiswa

\begin{tabular}{lcc}
\hline Uraian & Sebelum & Sesudah \\
Mahasiswa Kurang Berminat & 19 & 3 \\
Mahasiswa Berminat & 3 & 18 \\
Mahasiswa sangat Berminat & 3 & 4 \\
\hline
\end{tabular}

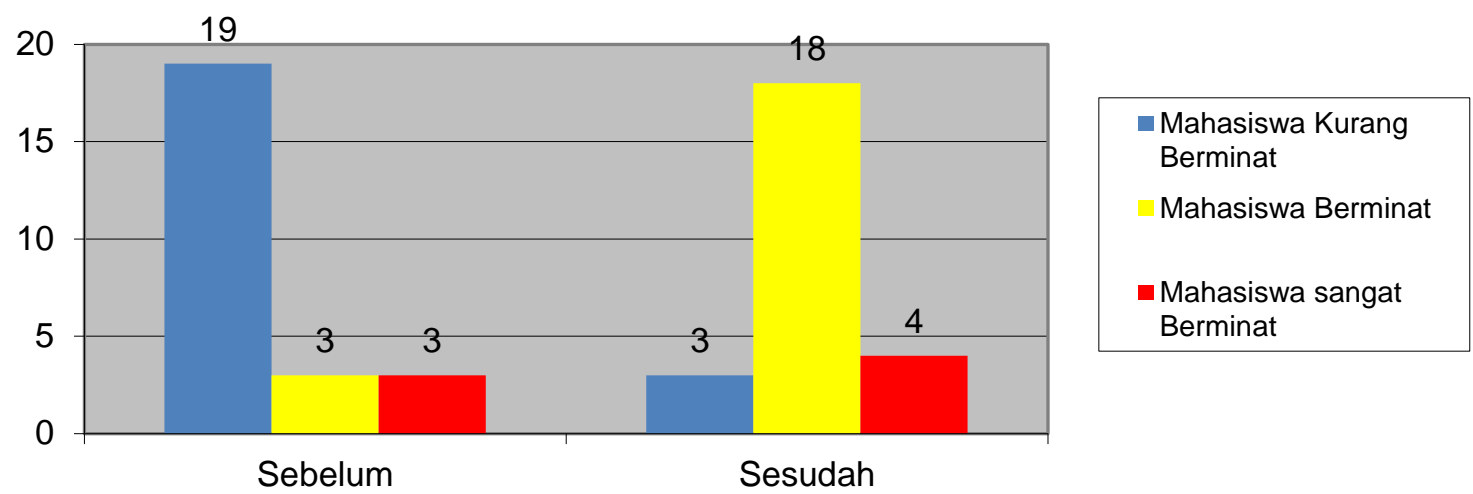

Gambar 3. Grafik Minat Mahasiswa

Setelah penelitian ini dilaksanakan setidaknya ada tiga aspek terangkum, kemudian dilaukan analisa data Sebagai berikut :

\section{Kemampuan Pemecahan Masalah Mahasiswa}

Kemampuan Pemecahan Masalah Mahasiswa di kegiatan siklus I pada matakuliah matematika teknik 2 Politeknik Harapan Bersama, dari hasil rekap nilai ujian sebagai hasil evaluasi memperoleh 
hasil rerata 65 dengan tingkat prosentase ketuntasan 55\% hasil ini memberikan pemahaman bahwa proses pembelajaran belum memperoleh target yang diharapkan dengan standart nilai minimal 70 dan tingkat kelulusan $\geq 85 \%$. Dan data yang diperoleh dari hasil refleksi dengan rekap tingkat kesulitan yang dialami oleh mahasiswa dalam materi matematika teknik 2. Dan karena belum mencapai target pembelajaran yang diharapkan sehingga dilakukan siklus II yang melalui proses koordinasi dengan observer dosen dan kemudian melakukan proses pembelajaran menggunakan bantuan software matematika yaitu Wolfram Mathematica. Pelaksanaan siklus II dilakukan dengan proses pembelajaran yang dilengkapi dengan evaluasi untuk memperoleh data Kemampuan Pemecahan Masalah Mahasiswa baik secara individu maupun kelompok, dan diharapkan dengan peningkatan prestasi yaitu dengan peningkatan kemampuan pemecahan masalah. Dari proses pengambilan nilai yang diambil dengan nilai individu dan kelompok, memiliki tujuan yaitu dengan meningkatnya kemampuan Kelompok nanti pada gilirannya akan meningkat kepada kemampuan individu. Dan hasil evaluasi yang di peroleh memperlihatkan perolehan nilai rerata mahasiswa 78 dengan prosentase $90 \%$. Hasil ini memberikan pemahaman adanya peningkatan prosentase belajar adalah $75 \%$ dengan rerata peningkatan sebesar $17 \%$.

\section{Aktifitas Mahasiswa}

Kegiatan aktifitas belajar siklus I pada mahasiswa semester 2 Matakuliah Matematika Teknik Prodi Teknik Mesin Polharber Tahun Akademik 2019/2020 pada hasil siklus I dan II menggambarkan perubahan positif yang cukup signifikan, peningkatan ini terlihat pada prosesntase siklus I sebesar 35\% menjadi $85 \%$ pada siklus 2 sehingga dari peningkatan nilai itu dapat disimpulkan bahwa mahasiswa tergolong aktif dalam proses pembelajaran. Dalam proses peningkatan aktifitas mahasiswa diperlukan inovasi dalam proses pembelajaran yaitu dengan menggunakan komputasi matematika yang dapat membantu mahasiswa dalam menyelesaikan terkait pemecahan masalah dalam matematika (Qurohman, 2018). Dan harapannya dengan kegiatan ini Dosen dapat memberdayakan mahasiswa, dan mengetahui respon mahasiswa. Pengamatan ini menjadi hal yang bersifat prioritas karena dapat memacu rasa ingin tahu dan motivasi mahasiswa. Kemudian dalam kelompok belajar yang telah dibentuk mahasiswa di arahkan untuk dapat mencapai tujuan pembelajaran secara masksimal. Harapan berikutnya adalah dengan pengetahuan dan pengalaman yang terjadi dalam proses pembelajaran diharapkan membantu pengalaman belajar yang bersifat dinamis dan efektif. Serta dengan dibentuknya kelompok, di harapkan peningkatan kemampuan yang terjadi dikelompok kemudian terjadi peningkatan pada pribadi mahasiswa. Dan dengan menyeimbangkan antara materi dan metode yang diberikan di harapkan mahasiswa dapat memahami materi perkuliahan lebih baik lagi (Qurohman et al., 2019).

\section{Motivasi Mahasiswa}

Metode inovasi pembelajaran dengan bantuan software komputasi ini berdampak secara langsung, hal ini terlihat dari meningkatnya minat mahasiswa. Salah satu yang menjadikan minat mahasiswa 
meningkat tentunya di perngaruhi beberapa faktor diantaranya lingkungan, motivasi, pengalaman, dan pemahaman, serta dari Pendidik (Dosen). Melalui pembelajaran ini mahasiswa merasakan proses pembeajaran yang sangat menyenangkan dan berharga. Hal ini senada dengan tujuan utama dalam peningkatan kualitas proses pembelajaran. Variabel yang di lakukan asesment : Proses, Produk dan hasil kinerja yang kemudian di ambil kesimpulan akhir. Kemudian mahasiswa juga dilatih dengan diberi tugas tambahan sebagai sarana melatih kemampuan diri, dengan di arahkan untuk mendekatkan matakuliah dengan kehidupan nyata. Sehingga dengan melibatkan mahasiwa kedalam proses pembelajaran yang mengedepankan teknologi komputasi semakin membuat motivasi mahasiswa menjadi meningkat (Qurohman, 2017). Beberapa penelitian yang telah terlaksana memberikan indikator bahwa penggunaan komputasi matematika dapat meningkatkan kemampuan dan motivasi dari peserta didik (Romadhon \& Qurohman, 2017).

\section{KESIMPULAN}

Dari Riset yang telah dilaksanakan diperoleh kesimpulan yang menjelaskan bahwa penggunaan teknologi komputasi khususnya dengan Wolfram Mathematica ini sangat efektif dalam memberikan motivasi kepada mahasiswa yang mengikuti perkuliahan matakuliah matematika teknik 2, sehingga prestasi dapat meningkat dengan cukup signifikan dengan penjabaran sebagai berikut : (1) Dari rekap nilai kuisioner yang diberikan kepada mahasiswa bahwa pada proses pembelajaran yang dilaksanakan, dimana pada nilai kemampuan awal yang hanya $24 \%$ mengalami peningkatan menjadi $88 \%$ pada siklus II ; (2) Terjadi peningkatan pada aspek aktifitas belajar mahasiswa yang menggunakan bantuan aplikasi komputasi wolfram mathematica pada mahasiswa semester 2, dengan perolehan rerata siklus 165 dengan nilai mahasiswa yang tuntas sebesar 55\%. Kemudian nilai rerata mahasiswa pada siklus ke 2 adalah 77 dan pada tingkat ketuntasan yang di peroleh sebesar 98\%. Sehingga dengan demikian dapat disimpulkan bahwa pengunaan software komputasi Wolfram Mathematica yang digunakan efektif untuk meningkatkan Kemampuan Pemecahan Masalah Mahasiswa pada program penelitian tindakan kelas.

\section{DAFTAR PUSTAKA}

Muhtarom, M., Sutrisno, S., \& Murtianto, Y. H. (2015). Pengembangan Bahan Ajar Berbantuan Software Mathematica dalam Mengembangkan Kemampuan Representasi matematika Mahasiswa Pengembangan Bahan Ajar BerbantuanSoftware Mathematica dalam Mengembangkan Kemampuan Representasi matematika Mahasiswa. November, 355-363.

Qurohman, M. T. (2017). Meningkatkan Kemampuan Pemecahan Masalah Kalkulus Lanjut Melalui Pembelajaran Kooperatif Tipe Co-Op Co-Op. Cakrawala: Jurnal Pendidikan, 11(1), 32. https://doi.org/10.24905/cakrawala.v11i1.664

Qurohman, M. T. (2018). Think to Talk Write Learning Mathematics Tool Hands on Activity. 
Peningkatan Kemampuan Pemecahan Masalah Mahasiswa DIII Teknik Mesin dengan Software Wolfram Mathematica,

International Journal of Trends in Mathematics Education Research, 1(3), 95-99. https://doi.org/10.33122/ijtmer.v1i3.78

Qurohman, M. T., Sungkar, M. S., Abidin, T., \& Polytechnic, H. B. (2019). Development of Mathematics Learning Application Based on. 06(02).

Romadhon, S. A., \& Qurohman, M. T. (2018). Using Movie to Increase Students' Vocabulary in Politeknik Harapan Bersama. IJECA (International Journal of Education and Curriculum Application), 1(2), 104. https://doi.org/10.31764/ijeca.v1i2.2149

Romadhon, S. A., \& Qurohman, M. T. (2017). the Advantages of Youtube To Enhance Student'S Vocabulary in Mechanical Engineering Classroom. Wiralodra English Journal, 1(1), 14-20. https://doi.org/10.31943/wej.v1i1.13

Shodiqin, A., \& Belakang, L. (1995). Pembelajaran Matematika Dengan Bantuan Software. 1-22.

Sunaryo, Y. (2020). Peningkatan Kemampuan Representasi Matematis Melalui Pembelajaran Berbasis Masalah Berbantuan Software Wolfram Mathematica. JNPM (Jurnal Nasional Pendidikan Matematika), 4(1), 85. https://doi.org/10.33603/jnpm.v4i1.2683 